\title{
Haemophagocytic Syndrome Associated with Hepatitis E infection
}

\author{
KS Somasekhar Rao*, Geethika, Y Srinivas and Naveen Polavarapu \\ Department of Gastroenterology and Department of Medicine, Apollo Hospital, Hyderabad, India \\ *Corresponding Author: KS Somasekhar Rao, Department of Gastroenterology and Department of Medicine, Apollo Hospital, \\ Hyderabad, India.
}

Received: July 03, 2019; Published: July 23, 2019

DOI: $10.31080 /$ ASGIS.2019.02.0061

\begin{abstract}
We report a rare case of hemophagocytic lymphohistiyocytosis secondary to a Hepatitis E infection in a young 40 year old lady. Hemophagocytic lymphohistiyocytosis is a life threatening syndrome of hyper immune activity. HLH most commonly affects neonates to children up to age of 18 months, but can be seen in children and adults of all ages. Infants are most commonly affected, with the highest incidence in those $<3$ months [1]. The male to female ratio is close to 1:11. In adults, there may be a slight male predisposition [2].
\end{abstract}

Keywords: Hemophagocytic; Hepatitis E

\section{Case Report}

A previously apparently alright lady presented to our hospital with history of fever for 10 days. Prior to presenting to our hospital she was admitted at local hospital for complaints of abdominal pain and shortness of breath. There she was investigated and found to have normocytic normochromic anaemia ( $\mathrm{Hb}-10.6 \mathrm{gm} /$ $\mathrm{dL}$ ), leucopoenia (total leukocyte $-1600 / \mathrm{mm}^{3}$ ), thrombocytopenia (total platelet count $-40,300 / \mathrm{mm}^{3}$ ), peripheral smear was reported normal. Her blood biochemical analysis revealed hypercreatinemia (Serum Creatinine - 6.37mg/dL), hyperuremia (Serum urea - $211.7 \mathrm{mg} / \mathrm{dL}$ ), hyperbilirubinemia (Serum bilirubin - $16 \mathrm{gm} / \mathrm{dL}$ ). She was transfused with 4 units of random donor platelets and was subjected to haemodialysis, before presenting to our hospital 4 cycles of haemodialysis were done for her. Medication history was not available at the time of admission. In view of worsening blood parameters and clinical deterioration she was referred to our centre for further management. On presentation she was dyspnoeic, tachycardic and tachypnoeic. On examination she was conscious and obeying commands, febrile with temperature: $100^{\circ} \mathrm{F}$, she was icteric had pallor, bilateral lower limb oedema, hepato- splenomegaly and ascites. Investigations for her showed have normocytic normochromic anaemia $(\mathrm{Hb}-8.2 \mathrm{gm} / \mathrm{dL})$, neutrophilic leucocytosis (total leucocyte $-15600 / \mathrm{mm}^{3}$ ), total platelet count $140,000 / \mathrm{mm}^{3}$, peripheral smear was reported normal. Her blood biochemical analysis revealed hypercreatinemia (Serum Creatinine - 3.6mg/dL), hyperuremia (Serum urea - 72mg/dL), hyperbilirubinemia (Serum bilirubin $-11.1 \mathrm{mg} / \mathrm{dL}$ ) predominantly conjugated - 9.5gm/dL, hypertriglyceridemia (serum triglyceride - 285mg/ $\mathrm{dL}$ ), hypoproteinemia (serum protein $-4.0 \mathrm{gm} / \mathrm{dl}$ ), transaminitis (AST - 455U/L, ALT - 106U/L), high GGTP levels - 122U/L, ALP - 279U/L, serum amylase - 189U/L, lipase - 830U/L. Her blood coagulation was deranged and workup showed D - Dimer - 7700, aPTT - 42.7 seconds, PT - 18.9 seconds, TT - 24.7 seconds. Serum LDH - 2616U/L, FDP in blood was $40 \mu \mathrm{g} / \mathrm{mL}$, plasma fibrinogen was $282 \mathrm{mg} \%$, serum CPK - 848U/L. Further evaluation for fever was negative for Malaria parasite, Leptospira, Ricketssial infection, Dengue infection, Hepatitis A infection, Hepatitis B infection, Hepatitis $\mathrm{C}$ infection, and was reported positive for Hepatitis $\mathrm{E}$ infection (HEV IgM). Also urine culture grew Enteroccocus. Following this she was started on antibiotics as per culture sensitivity report. But the fever spikes persisted, also repeat laboratory parameters revealed worsening pancytopenia $(\mathrm{Hb}-8.4 \mathrm{gm} / \mathrm{dl}$, leukocyte -3600 / 
$\mathrm{mm}^{3}$, platelet $-80,000 / \mathrm{mm}^{3}$ ), hyperbilirubinemia total serum bilirubin $-18.6 \mathrm{mg} / \mathrm{dl}$ and predominantly conjugated $-14.9 \mathrm{gm} / \mathrm{dL}$, AST - 127U/L, ALT - 89U/L, GGTP - 249U/L, ALP - 190U/L, hypoproteinemia $-4.2 \mathrm{gm} / \mathrm{dL}$, Serum triglyceride increased to $623 \mathrm{mg} /$ dL. Further investigations were done to rule out intra-abdominal infection. CT abdomen revealed bulky pancreas. To confirm the aetiology PET-CT abdomen was done that was negative for infectious or malignant cause. With suspicion of Hemophagocytic syndrome and to rule out the cause of pancytopenia, bone marrow examination was done that revealed hypoplastic marrow with hemophagocytic predominance. Also the serum ferritin for her was elevated $(26200 \mathrm{ng} / \mathrm{mL})$. And hence a diagnosis of HLH was made as per the diagnostic guidelines of HLH - 2004 trial protocol. She was then started on HLH treatment as per HLH protocol 2004, she was on Injectable Dexamethasone $16 \mathrm{mg}$ once daily, Injectable Etoposide $250 \mathrm{mg}$ following this, the fever spikes decreased but hyperpyrexia persisted along with pancytopenia and worsened other laboratory parameters. On $12^{\text {th }}$ day of admission she died following a sudden onset bradycardia.

\begin{tabular}{|c|c|}
\hline $\begin{array}{l}\text { * Diagnostic Criteria for HLH as per HLH - } \\
2004 \text { protocol }\end{array}$ & $\begin{array}{l}\text { In Our } \\
\text { Patient }\end{array}$ \\
\hline $\begin{array}{l}\text { Molecular identification of an HLH associated } \\
\text { gene mutation (i.e., PRF1, UNC13D, STX11, } \\
\text { STXBP2, Rab27A, SH2D1A, or BIRC4). }\end{array}$ & NA \\
\hline \multicolumn{2}{|l|}{ OR } \\
\hline Five of the following eight findings & In Our Patient \\
\hline Fever $\geq 38.5^{\circ} \mathrm{C}$ & YES \\
\hline Splenomegaly & YES \\
\hline $\begin{array}{l}\text { Peripheral blood cytopenia, with at least two } \\
\text { of the following: haemoglobin }<9 \mathrm{~g} / \mathrm{dL} \text {; Plate- } \\
\text { lets }<100,000 / \text { microL; absolute neutrophil } \\
\text { count }<1000 / \text { microL }\end{array}$ & YES \\
\hline $\begin{array}{l}\text { Hypertriglyceridemia (fasting triglycerides } \\
>265 \mathrm{mg} / \mathrm{dL} \text { ) and/or hypofibrinogenemia (fi- } \\
\text { brinogen }<150 \mathrm{mg} / \mathrm{dL} \text { ) }\end{array}$ & YES \\
\hline $\begin{array}{l}\text { Hemophagocytes in bone marrow, spleen, } \\
\text { lymph node, or liver }\end{array}$ & YES \\
\hline Low or absent NK cell activity & NA \\
\hline $\begin{array}{l}\text { Ferritin }>500 \mathrm{ng} / \mathrm{mL} \text { (the author prefers to } \\
\text { consider a ferritin }>3000 \mathrm{ng} / \mathrm{mL} \text { as more in- } \\
\text { dicative of HLH. }\end{array}$ & YES \\
\hline $\begin{array}{l}\text { Elevated soluble CD25 (soluble IL2 } \\
\text { receptor alpha) two standard devia- } \\
\text { tions above age adjusted laboratory } \\
\text { specific norms }\end{array}$ & NA \\
\hline
\end{tabular}

N.A. - Not Available.
HLH can be familial as well as sporadic. Events and factors causing disruption of immune mechanism triggers $\mathrm{HLH}$, thus infections are the most common triggering factor of HLH and can be triggering factor in both familial and sporadic HLH.

Being predominantly a paediatric disease and also the literature for adult cases being very few till date it becomes difficult to diagnose the case. Because of this rarity of disease usually there is delay in diagnosis of HLH and thus increasing the mortality rate associated with HLH. The initiation of treatment should be prompt once diagnosed HLH.

Primary HLH, also called familial hemophagocytic lymphohistiocytosis (FHL), refers to HLH caused by gene mutation, either at one of the FLH loci or in a gene responsible for one of several immunodeficiency syndromes. The FHL loci include FHL1 (OMIM 267700); FHL2 (OMIM 603553); FHL3 (OMIM 608898);FHL4 (OMIM 603552);andFHL5 (OMIM 613101). Additional genetic loci for HLH include GS2 (OMIM 607624); CHS1 (OMIM 214500); HSP2 (OMIM 608233); XLP1 (OMIM 308240);and XLP2 (OMIM 300635) [3].

Secondary or sporadic or acquired HLH are those without a known familial mutation. In adults; and patients in whom a clear trigger of the HLH episode has been identified (e.g., viral illness, autoimmune disease, lymphoma). However, many patients with "secondary HLH" do in fact have a genetic defect associated with the syndrome (e.g., heterozygous defect, mutation resulting in partial protein expression), and many patients with primary HLH experience symptoms in response to one of these triggers and hence the ambiguity regarding the term 'Secondary'.

Macrophage activation syndrome - Macrophage activation syndrome (MAS) is a form of HLH seen primarily in patient with juvenile idiopathic arthritis or other rheumatologic diseases in adults can be seen in patients with Adult Onset Still's disease.MAS is also termed as 'reactive hemophagocytic syndrome'.

Other terms not very frequently referred for HLH include virus associated hemophagocytic syndrome, hemophagichistiocytosis, familial erythrophagocytic lymphohistiocytosis (FEL), and viral associated hemophagocytic syndrome (VAHS) [3-8].

HLH is a syndrome of excessive inflammation and tissue destruction due to abnormal immune activation and excessive inflammation. In general, a lack of normal down regulation of activated macrophages and lymphocytescan be attributed to the excessive inflammation. Excessive cytokine production by macrophages, NK cells, and CTLs is thought to be a primary mediator of tissue damage [9]. 
HLH presents as a febrile illness associated with multiple organ involvement. Thus, initial signs and symptoms of HLH can mimic common infections, fever of unknown origin, hepatitis, or encephalitis.

In the HLH94 study of 249 patients, which is one of the largest cohorts described, prominent clinical signs included the following [10]

- $\quad$ Hepatomegaly - 95 percent

- $\quad$ Lymphadenopathy - 33 percent

- Neurologic symptoms - 33 percent

- $\quad$ Rash - 31 percent.

Although intravenous immunoglobulin (IVIg), steroids, plasmapheresis and cytotoxic agents have been tried in the therapy of viral infection associated hemophagocytosis with varying success rates, there is no standard therapy. And thus the prognosis of viral associated haemophagocytic syndrome remains variable with increase fatality rate.

Till date to best of our knowledge this is third case to be reported with HLH secondary to hepatitis E infection $[11,12]$.

\section{Acknowledgement}

None of the authors reported any conflict of interest.

\section{Bibliography}

1. Henter JI., et al. "Incidence in Sweden and clinical features of familial hemophagocytic lymphohistiocytosis". Acta Paediatrica Scandinavica 80 (1991): 428.

2. RamosCasals M., et al. "Adult haemophagocytic syndrome". Lancet 383 (2014): 1503.

3. Larroche C. "Hemophagocytic lymphohistiocytosis in adults: diagnosis and treatment". Joint Bone Spine 79 (2012): 356.

4. Henter JI., et al. "HLH2004: Diagnostic and therapeutic guidelines for hemophagocytic lymphohistiocytosis". Pediatric Blood and Cancer 48 (2007): 124.

5. Aricò M., et al. "Hemophagocytic lymphohistiocytosis. Report of 122 children from the International Registry. FHL Study Group of the Histiocyte Society". Leukemia 10 (1996): 197.

6. Reiner AP and Spivak JL. "Hematophagichistiocytosis. A report of 23 new patients and a review of the literature". Medicine (Baltimore) 67 (1988): 369.
7. Clementi R., et al. "Adult onset and atypical presentation of hemophagocytic lymphohistiocytosis in siblings carrying PRF1 mutations". Blood 100 (2002): 2266.

8. Janka GE, Schneider EM. "Modern management of children with haemophagocytic lymphohistiocytosis". British Journal of Haematology 124 (2004): 4.

9. Filipovich A., et al. "Histiocytic disorders: recent insights into pathophysiology and practical guidelines". Biology of Blood and Marrow Transplantation 16 (2010): S82.

10. McClain K. "Clinical features and diagnosis of hemophagocytic lymphohistiyocytosis".

11. Kamihira T., et al. "Case of domestically infected hepatitis E with marked thrombocytopenia". Nippon Shokakibyo Gakkai Zasshi. 105 (2008): 841-846.

12. Kaur S., et al. "Hemophagocytosis Associated with Hepatitis A and E Coinfection in a Young Child". Indian Journal of Hematology and Blood Transfusion 27.2 (2011): 117-118.

\section{Volume 2 Issue 6 August 2019}

(C) All rights are reserved by KS Somasekhar Rao., et al. 